\title{
Introduction
}

\section{Towards Communities of Practice in Global Sustainability, Part Two}

\section{Carl A. Maida and Sam Beck}

This is Part Two of a set of articles related to how communities of practice inform global sustainability; a more extensive introductory essay (Maida and Beck 2016) is included in the first of this two-part special issue. The community of practice is an organisational form, which since the late twentieth century, has accelerated with advances in information production and dissemination (Wenger 2000). Communities of practice ensure greater engagement for sustainability by a public as local and global actors. As a paradigm that arose through the anthropological imagination, the community of practice is an organisational form that complements the current knowledge economy (Lave 1988).

The sustainability narrative focuses on the physical development and institutional practices that meet the needs of people using them in the present, without compromising the ability of future generations to meet their own needs, particularly with regard to use and waste of natural resources (Maida 2007). To this end, sustainable practices support ecological, human and economic health and vitality, with the presumption that resources are finite, and should be used with a view to long-term priorities and consequences. However, cultivating sustainability literacy and public engagement on its behalf requires diverse cultural perspectives, trans-generational timeframes and localto-global connectedness. The need to promote participatory approaches to sustainability literacy in the broader public is clear, however few communitybased approaches have been developed to date that integrate disciplines into a holistic perspective of Earth's natural and human systems. Defining and securing a satisfactory quality of life for localities affected by restrictions resulting from capitalist stateand market-based commodification of the natural, so- cial and cultural commons, including public space, is a key feature of the sustainability project (Klein 2014).

Anthony Giddens' notion of life politics, or those movements that challenge contradictions of capitalist growth and technological development through reflexive and existential means, is especially instructive (Giddens 1991). Without community-based institutions, the more successful of which combine the skill sets of both experts and lay people, and continuously provide new types of hybrid social knowledge for people caught up in these changes, considerable suffering and clearly less progress in meeting these challenges prevail. Social suffering, in this sense, is caused by human and natural disorders and inversions that threaten to destroy the sociocultural fabric of the modern world, understood by Roy Rappaport as environmental degradation, population increase, warfare, globalisation, development and threats to cultural autonomy (Rappaport 1994).

Returning now to the community-based concerns of anthropologists engaged in sustainability research and practice, using an operational framework of a community of practice is instructive. All communities of practice contain three structural elements: domain, or the area of shared enquiry; community, or the environment where relationships are built; and practice, or the body of knowledge, methods, tools, cases and stories put into action. A community of practice, therefore, is comprised of individuals who share a common interest in a specific domain of knowledge (Lave 1996). However, to sustain a knowledge commons, in this sense, communities of practice can work towards diminishing the boundaries between the expert producers of such knowledge within the academic, public, non-profit and private sectors, and lay consumers across these sectors on behalf of local and 
global sustainability. Translating anthropological research into action promotes better understanding, so that both experts and the lay public may meaningfully engage in informed dialogues about their common concerns for sustainable communities (Beck and Maida 2015). Collaborative methods, such as participatory research, will ensure a more socially responsive sharing of anthropological knowledge across diverse sectors and constituencies. A critical anthropological approach also orients participants towards a deeper democratic lifeway, creating the opportunity for 'environmental stewardship' and 'global citizenship', even at the local level.

This two-part special issue focuses on eight casebased articles and one theoretical article on communities of practice, within and beyond anthropological frameworks, to illustrate how participatory researchers, students, policy and community leaders, and the broader public, come to engage in community-based transformational sustainability research and practice. Authors discuss in their articles how networks of researchers, practitioners and experts communicate with a wider audience to translate sustainability concepts into terms broadly understood by the public, and on how emergent communities of practice ensure greater engagement by a public, as citizens, activists and citizen scientists, locally, regionally, nationally and globally. The authors also address the ways that class, gender and ethnicity play a role in how these communities meet the challenges of global sustainability. Within this framework, contributors explore communities of practice on behalf of rural and urban sustainability in Latin America, Asia, Europe and the United States. The first set of articles, in Anthropology in Action 23(1), focused on the Global North, specifically Western Europe and North America. The second set of articles, which appear in this issue, focus on the Global South, specifically South America and South Asia. Linda D'Amico describes the ways rural women and men in the Ecuadorian Cloud Forests created regional and trans-regional institutions to develop and sustain effective environmental governance that offer examples of expanded social equity and adaptive resilience in the face of change. Debarati Sen examines how fair trade-engendered solidarity practices in Darjeeling's tea plantations erase the complex history of workers' struggle with the state and established systems of power through collective bargaining, which, in turn, produce new kinds of transnational praxis affecting the plantation public sphere. Carla Guerrón Montero explores the relationships among state, culture and politics in the context of the largest educational project of social inclusion, local participation and citizenship in the Municipality of Camaçari, state of Bahia, northeastern Brazil, in a community of practice where stakeholders are potentially producing a new way to understand what it means to be a modern Brazilian citizen. Marta Crivos, María Rosa Martínez, Laura Teves and Carolina Remorini depict how intersectoral forums with governmental and non-governmental actors and local residents helped bring about joint reflection on viability and sustainability of local and global practices and resources in a rural community in the Calchaqui Valley (Salta, Argentina). Richard Westra discusses how all communities of practice face questions relating to the material economic foundations of future sustainable societies concerning economic scale and the re-localising of production and consumption sundered by globalisation, and focuses on the local exchange and trading system as a foundation of rich, eco-sustainable community material life.

\section{Acknowledgements}

We would like to thank the Organising Committee of the XVII World Conference of the International Union of Anthropological and Ethnological Sciences, held in Manchester, U.K. in August 2013, with the theme of Evolving Humanity, Emerging Worlds, for support of the session that would bring together the various authors in this special issue for a day of presentations, discussions and conviviality. We are grateful to Brian McKenna and Bruce Woych for their critical reading of this introduction and their suggestions for revision. We are also grateful to Marion and Vivian Berghahn, and to Christine McCourt, for their support during the entire process of putting this special issue together.

CARL A. MaIda is a professor at the UCLA Institute of the Environment and Sustainability in the College of Letters and Science, where he teaches courses on action research methods and conducts communitybased research on urban sustainability. His current research focuses on the ongoing dialogue between professional and lay knowledge in the areas of health, the quality of life and sustainability of urban communities, and on the larger national and global debates on access to public goods. He is a member of the UCLA Campus Sustainability Committee and chairs its Academic Committee. He is a Fellow of the American Association for the Advancement of Science, the American Anthropological Association and the Society for Applied Anthropology. E-mail: cmaida@ucla.edu 
SAM BECK is Senior Lecturer at Cornell University where he directs the Urban Semester Program. He has dedicated himself in the last twenty years to an activist role as an anthropologist carrying out research in North Brooklyn. As such he is an active Executive Board member in local community-based organisations that insist on being recognised with dignity and respect and struggle for community sustainability. He is a member of the Vernon Avenue Project and its spinoff Reconnect Industries, Churches United for Fair Housing, The Grand Street Boys and Brooklyn Legal Services A. He has received multiple awards for his community service work and as a teacher. E-mail: sb43@cornell.edu

\section{References}

Beck, S. and C. A. Maida (eds.) (2015), Public Anthropology in a Borderless World (New York: Berghahn).
Giddens, A. (1991), Modernity and Self-identity: Self and Society in the Late Modern Age (Stanford, CA: Stanford University Press).

Klein, N. (2014), This Changes Everything: Capitalism vs. The Climate (New York: Simon and Schuster).

Lave, J. (1988), Cognition in Practice (New York: Cambridge University Press).

Lave, J. (1996), 'Teaching, as Learning, in Practice', Mind, Culture, and Activity 3, no. 3: 149-64.

Maida, C. A. (ed.) (2007), Sustainability and Communities of Place (New York: Berghahn).

Maida, C. A. and S. Beck (2016), 'Towards Communities of Practice in Global Sustainability', Anthropology in Action 23, no. 1.

Rappaport, R. (1994), 'Disorders of Our Own', in Diagnosing America: Anthropology and Public Engagement, (ed.) S. Forman (Ann Arbor: The University of Michigan Press), 235-94.

Wenger, E. (2000), 'Communities of Practice and Social Learning Systems', Organization 7, no. 2: 225-46. 